\title{
CRISES AND REFORMS IN EDUCATION: HISTORICAL PERSPECTIVE FROM LATVIA
}

\author{
Iveta Kestere \\ University of Latvia, Latvia
}

\begin{abstract}
Using cases of the past, the article aims at analysing topical problems arising in the context of education reforms. The study focuses on such issues as crisis and "crisis rhetoric", reforms as a product of crisis, and main actors of crises and reforms. In the first part of the article, three cases of the $20^{\text {th }}$ century crises and reforms are used to explain what is considered a crisis and why the annunciation of the educational crisis in public space is so permanently attractive. The second part of the article focuses on common features of the $20^{\text {th }}$ century reforms, namely, calls for moving school closer to life and for activating the learning process, as well as the role of social movements and political support in education reforms. The article looks at the divergent interests of reformers and consumers of education, the discrepancy leading to failure of reforms and forcing again and again to return to the tasks that have already been addressed by previous generations of reformers. The third part characterises reformers' and "ordinary" teachers' stance in relation to reforms and explains why reformers are interested and teachers are cautious. In conclusion, crises and reforms are acknowledged as an inevitable and cyclical part of the educational process, for in the field of education, all actors - reformers, education consumers (students and their parents), employers and teachers - play by their own rules and pursue their own agendas. So, to reconcile their interests is a laudable but utopian project. However, reforms also have their positive side - they activate school practices, expand teacher cooperation and raise public debate over education issues.
\end{abstract}

Keywords: crisis of education, education reform, education policy, history of education.

\section{Introduction}

The crisis in education has been reigning for 5000 years. Since the emergence of schools in the third millennium BC, society has been constantly dissatisfied with the curriculum, forms and methods of teaching 
and teachers themselves. In their turn, teachers have been dissatisfied with students and their parents, and their pay. Long history tells a lot (Apple, $2015,10)$. Sources list innumerable examples of the worst situation that had ever happened so that the education system was ready to collapse right there and then. For example, Johann Jacob Harder (1734-1775), the rector of Riga Charles Lyceum, complains that there are many indifferent among youngsters, for whom school is of secondary importance, those who think about other things during the lesson, who do not do their homework and have read close to no books beyond required reading. Instead, they are interested only in outings, promenades, parties and theatres. Reprimanded by the teacher, they become resentful and even more negligent of their school duties. There happen parents who tell their children that it is no worth studying much: with enough money and goods, one can always get ahead in life, so they have to sit at school so far that there is nothing else yet to do (quoted from Johansons, 1975, 155). Thus, in the distant $18^{\text {th }}$ century, neither students nor their parents pleased teachers, and there was no shortage of problems in school.

Crisis announcements are heard in modern Latvian education space too: in newspapers published after Latvia regained its independence in 1991, a crisis in education or at some of education level is declared every year. For instance, in 1995, the article "Is it Only the Education Crisis?" (Seleckis, 1995); in 2000, "The Crisis in Education Threatens the Whole Country's Future" (Gintere, 2000); in 2007, "School in the Centre of the Crisis" (Vēbers, 2007).

Regularly diagnosed crises as well as the current education reform 'School 2030' (Skola 2030) in Latvia gave me impetus to focus on the permanent appeal of crises and reforms, the attractiveness evident in historical discourse. In the following text, three cases of the $20^{\text {th }}$ century crises and reforms which have affected education in Latvia are studied to address three issues, namely: 1) crisis and "crisis rhetoric"; 2) reforms as products of crises; 3 ) actors of crises and reforms.

\section{Crises. Three $20^{\text {th }}$ Century Cases}

First of all, why in education crisis announcement is so popular.

Ethan Hutt has conveyed a US magazine analysis and his results are telling: since 1910, the use of the word 'crisis' has grown eightfold, becoming a permanently used lexeme in educational periodicals (Hutt, 2016). Heinz-Elmar Tenorth joins Hutt writing that "the rhetoric of crisis in pedagogy has become classic" (Tenort, 1999, 442).

The term 'normal crisis' has been introduced in the public space and a typology of crises, e.g. 'Teacher Competence Crisis', 'Equal Opportunity 
Crisis', 'Moral Authority Crisis', 'Value Crisis', 'Upbringing Crisis', has been created (Hutt, 2016). Scholars discuss scientific, publicity and private discourses of crises (Hemetsberger, 2018, 101). Crisis is a notion, concept, event. Paraphrasing Michael W. Apple $(2015,10)$, the word 'crisis' is used so widely that it loses any sense, it turns rhetorical, and no one is sure about its meaning anymore. Crisis rhetoric, however, does not lose it vitality.

Crisis appeal has various causes:

1) Crisis "opens" the future. It raises questions and forces to search for answers in assessing visions of future (Hemetsberger, 2018, 102). Everybody is ready to give their opinion about the future of education; it is "everybody's business" (Tyack, Cuban, 2003, 6), for all went to school and therefore they are certain of their expertise in education issues.

2) Crisis gives the incentive to work - it grounds, legitimises and justifies changes. Crisis can be used to justify mistakes in reforms.

3) Crisis allows an individual or a group to become a saviour or at least to look like one. The possibility of drama makes crisis especially attractive (Hemetsberger, 2018, 107). Pessimists always look wiser than optimists. Heralds of crisis leave the impression that they have some special knowledge and it, of course, makes them particularly smart and important in the eyes of general public. That is why crisis is often announced by politicians, education experts, mass media and community enthusiasts.

Further, using three cases of the $20^{\text {th }}$ century, I will disclose mechanics, problems, and some lessons of crises and subsequent reforms, if of course we accept that it is possible to learn from history.

The first crisis and education reforms. The end of the 19th - the first third of the $20^{\text {th }}$ century. "Old" school versus "New" school. In the end of the $19^{\text {th }}$ century, not only politicians and professional pedagogues insisted on changes in education, general public demanded change too. The press did not only call for reforms, it called for a revolution. Society banded together against the "old" school with its physical and psychological violence and concomitant suicides of pupils. The latter had reached an all-time high level in Germany: in 14 years 165 children younger than 15 years old committed suicide in Berlin schools (Sheibe, 1999, 68). School were accused of ignoring the child's personality, suppressing freedom, naturalness and vitality, and of disconnectedness of learning from real life. School was given such names as "School of Books and Teachers", "Factory", "Drilling School", "Museum of Dead Treasures", "Squeezing School", "School of Punishment" (Sheibe, 1999, 75). Latvian pedagogues joined their western European colleagues: "The "old" school asked from the pupils 
just to sit in the classroom, listen, learn and allow himself to be guided by the teacher" (Soste, 1920, 193).

In the public space of educational journal and conferences, ideas of school reforms flared up every minute. There appeared Dewey's Laboratory School in Chicago, Montessori's Children's House in Rome, Decroly's Hermitage School of learning for life through life ("Let the child prepare for life by living") in Brussel, Arbeitschule in Hamburg and countless other education practices and theories around the world. In Latvia, the role Finland plays today was performed by Germany. Latvians were not shy - they went to study in Belgium under Ovide Decroly, invited to Riga Hugo Gaudig from Germany (Zigmunde, 2010). Latvia was inspired by the very best examples of the New School/Reformpädagogik. By the mid-1930s, the initiative of the Latvian Teachers' Union brought a broad teacherexperimenter movement in operation, with its main task to step up school teaching and related search for new methods, including the introduction of Arbeitschule (Marsone, Kestere, 2010). In Arbeitschule work, research, quest, study, defining problems and search for their solution were not conducted individually but in a close community with others (Dauge, 1922).

The second crisis and education reforms. The end of the 1950s mid 1960s. 'Sputnik-1'. In the history of Latvian education this crisis is the least researched despite its direct impact on the generation of current decision makers.

In October 1957, the USSR launched the artificial satellite Sputnik-1 into the Earth's orbit and declared it the victory of the socialist society over capitalists. It caused shock and even panic on the other side of the Iron Curtain (Hemetsberger, 2018, 107). A so-to-say surprising conclusion was made, and it was that Sputnik was a proof of the superiority of the Soviet education system. Therefore, there was an urgent need to change education in Western democracies. In 1957 a US Admiral Hyman G. Rickover declared that "Education is our first line of defence - make it strong". The slogans called: "Let's win against Russians in educational competition!" (Hemetsberger, 2018, 106, 108). Western education moved to visible standardisation, centralisation and scientification of curriculum (Tröhler, 2014, 14, 19). During the time, there saw the light OECD-funded comparative education statistics accompanied by "specific ideologies how society and its citizens should be shaped." (Tröhler, 2014, 17). Education became an important indicator of country development and its strategy of economic growth.

A nearly identical ideology governed Khrushchev's Educational Reform in 1958-59, when Latvia was part of the Soviet Union. Censured by the Communist Party, mass media could only mildly criticise the situation in education, for example, writing that "teachers, parents and society have 
to admit that there are serious shortcomings in school work" (Vìtina, 1958). It prepared the ground for the export of the education reform developed in Moscow to Soviet Latvia. As in the West, the public space was full of slogans with a military colouring: capitalism may be overcome in a "peaceful struggle" through the economic superiority of socialism (increasing automation and productivity). Thus, schools should be brought closer to life, which, of course, would prepare the working force for national economic development. Within the reform science and crafts classrooms were well equipped, boarding and special schools for talented children, and particularly in mathematics and the arts, were open (Coumel, 2009, Arsenjev..., 1988, 66-79). By the way, the phrase about the need to connect school to life has not disappeared from Latvian media in any of the following decades, thus, demonstrating the permanent topicality of the issue.

The third crisis and education reforms. The end of 1980s - mid1990s. Market-oriented education. The fall of the Berlin Wall and the collapse of the USSR. Overnight the collapse of the Soviet Union put a large part of Europe, including Latvia, in transit between command and market economy: "In the unprecedented circumstances of introducing a market economy in the ruins of a non-market economy, there were no precedents to indicate what should be done and how" (Rose, 2009, 17). In the confused post-Soviet society, everyone was looking for a new life model. There began experimentation in all spheres of life. The crisis of the centralised system of education and Moscow-periphery relations was aggravated by an ideological crisis. However, at the "bottom" of education, or in school practice, there was no time for idle talk - in schools, children were waiting to be educated there and then. The school routine quickly turned to what could be described as 'Europeanisation', 'democratisation', and 'market-oriented education' (Chankseliani, Silova, 2018). The pedagogical press reported about the search for new forms and methods of learning, introduction of the latest developments in psychology, opening of non-traditional schools and, as always, called for school to be linked to real-life needs (Kestere, 2010).

This brief crisis-reform overview allows to answer the question what exactly a crisis or "disaster in education" as Hemetsberger calls it (2018, $101)$ is. The short and simple answer is as follows: if there is indeed a crisis, there is no time to theorize about it, it is the time to act. The term 'crisis' appeared in medicine, where it was used to mark "that moment when death or recovery hangs in the balance" (Rikowski, 2017, 10). A "catastrophe in education" or crisis may be compared with a car accident when there is no time to analyse the situation but there is an urgent need to rescue its victims. In the time of salvation or reform, everyone is short 
of time (Hemetsberger, 2018, 101). Though if there is enough time for long discussions about reforms, there is no crisis, it is a "false alarm" or a "camouflage crisis", as Glenn Rikowski calls it (2017, 28).

\section{Reforms and Some of Their Lessons}

Reforming education is crisis rescue. That is why every crisis produces reforms. The aim of reforms is with effective and inconvenient methods to change the useless present (Hemetsberger, 2018, 101). All reformers share the common belief that if we change the curriculum and system, expand access to education and differentiate outcomes, society will lead a better life and every individual will have better opportunities (Labaree, 2012, 144).

However, reformers need a credibility mandate, and therefore they have to convince the public that their plan is at least good if not the best. In other words, an education reform should be sold. One option is to declare all opponents of the reform back numbers, and to hide the opposition as far as possible from the public eye (Terhart, 2013, 488) or at least marginalise it. Another option is to inveigle with the new, because the word 'new' itself has special power. Nicholas Burbules argues that education has constant fascination with the "new." He argues that in the educational market, promising that the "new" will definitely be better than the "old" works well, for the new is "exciting" and "cool" (Burbules, 2016, 9). Similarly, rapid innovations as a way out were offered in each of the three education crisis-reform cases examined above.

While each of the described cases is unique, they share a number of common attitudes that have to lead the community towards a happy future of education:

1) Studies have to be linked to real life. School should give skills required by the contemporary political, social and economic model of the society.

2) Learning process should be active. The environment is a learning tool. The boundaries of the subjects should be crossed. When learning, students should collaborate.

3) School should develop the child's individual abilities and talents.

Here I do not want to decent into banality saying that all has already taken place at some point in history (though, in fact, all has already taken place). A much more interesting question would be why in 50 or 100 years education reformers have to come back to the same tasks which were brought to life by previous generations of reformers. Why again and again we have to admit that school curriculum is cut off from real life? Why it is again actual to cross disciplinary boundaries, the approach called 'United 
Learning' in Latvia in the 1920s and 30s, the 'Complex Method' in English, and the 'interdisciplinarity' in Soviet pedagogy? The argument that in each epoch "linking school to life" is understood differently will not be valid here. It is obvious that education keeps returning to easy-to-count knowledge and separated subjects. It can be said that, despite the efforts of reformers, the system of education elegantly continues to live its own life (Labaree, 2012, 155) - to do a good job, namely, teaching children.

David F. Labaree explains the failure of reforms very pragmatically education is driven by evaluation (Labaree, 2012). Peter Abbs holds an even harsher view of education space: "In this grey institutional world of delivery and assessment..." (Abbs, 2003, 59). School is controlled by market and not by politicians and/or reformers. Whatever teachers might do in the learning process, it is ultimately reduced to assessment, namely, a diploma and a degree (Labaree, 2012). The conception of good education keeps changing, but the diploma remains a fundamental value. The diploma "normalises" institutions and careers (Apple, 2015, 3, 10). Before yesterday's pupils are given possibility to demonstrate their sustainable knowledge and diverse competences, first they are required to show their diplomas.

Here is an apparent contradiction between what education reformers and education consumers - students and their parents - want. Education reformers look at education as a solution to social problems and try to change the system, however consumers seek their individual good in education. With the help of education, consumers solve their own problems and not those of society. Consumers of education do not want to change school, they just want receive education converted in grades, degrees, certificates and to move on (Labaree, 2012, 145, 149). Labaree argues that pupils manoeuvre through school playing the game "how to succeed in school without really learning". He admits that this is not a bad thing, as students learn how to pursue their personal interests in an organized environment, and this is certainly useful in their future life. So, the primary goal of most pupils and their parents in the field of education is to obtain a diploma/degree ("hard currency of education") that opens the door to a good job and hence a comfortable life (Labaree, 2012, 147, 150). (At this point it is appropriate to reread Harder's characterisation of 18th-century students and their parents quoted at the beginning of this article.)

Employers also want to see clearly listed educational achievements, that is a diploma. Of course, with the advent of new technologies in our lives, the importance of diplomas and degrees seems to have diminished. Nonetheless, the lack of a diploma undoubtedly reduces opportunities in the labour market, and only a handful have become millionaires without a collage degree/high school diploma - even the biggest opponents of the 
"degree" have scrubbed up only a hundred, which is nothing against such an impressive number of millionaires and billionaires worldwide.

Well-paid posts in the European Union institutions open to EU citizens, including those from Latvia, testify to the importance of a diploma (so far). To apply for a vacancy, the starting point is a master's degree. No matter where it is obtained, even if it was received in a Soviet university. No need in reassuring that Soviet education is highly valued in Europe - it is not. The employer simply needs proof that the person has been purposeful and patient enough to spend a certain amount of time in an institutionalized educational setting and obtain a diploma/degree as a result. The rest is up to an employer, and in the case of competitions for seats in European institutions, they are tough, and they are won and lost by people with Soviet and Western diplomas. The important thing is that without a diploma no one can even apply for such competitions.

Another reason for the failure of reforms is smouldering nostalgia of the public for the "peaceful" past, which acquires an aura of particular attractiveness in the troubled times of reforms. As reforms move forward, the murmurings that "things were better in the past" are increasingly heard in the public space. It is testified by research carried out among teachers, for example, on the rating of the Soviet school today. Although respondents mention the ideologization of education, they mostly have positive memories that there were order and discipline in the school, pupils obtained thorough knowledge and that was good (Kestere, Lāce, 2004).

Thus, sooner or later, instead of reformers, education starts been led by its consumers (Labaree, 2012, 157). Reformers come and go, but consumers of education with their own needs remain. And school comes back to its comfort zone.

Apart from reforms of content and forms of studies, there are other aspects that unite all of the crisis-reform cases described above and made the reforms real.

The three education reforms of the $20^{\text {th }}$ century were not limited to education. They were part of reorganisation of society as a whole, in which various social groups enthusiastically took part. School can be changed only when the whole society is ready for changes (Labaree, 2012, 154). In the beginning of the $20^{\text {th }}$ century, Latvia saw growing activity of the movement for women's emancipation and various societies of non-formal learning. The enthusiasm for the formation of the national school also prevailed after the establishment of the Latvian state in 1918. The 1960s were characterised by Khrushchev's "thaw" that brought revitalisation and flowering of culture and gave the Iron Curtain a little lift. In the 1990s the liberation from the Soviet dictatorship dismantled the whole system of public life. Thus, listening to the ideas of current reformers, it is logical to 
ask what other social forces are participating in education reforms? Who else except reformers themselves are interested in reforming education? Who for are the initiated reforms?

Behind all three $20^{\text {th }}$ century education reforms in Latvia there were specific political forces. It is important. Public disposition increases or destroys the career capital of a politician, and, taking responsibility for reforms, the political force is interested and responsible for their success. Behind the reforms of the 1920s-30s reforms, there stood left movements, the Communist Party stood behind Khrushchev's reform, and the People's Front and the political party Latvian Way were behind the reforms of the 1990s. Then the next important question to start a broad education reform is what political force is/will be accountable for it? Who will be responsible for the reform at all?

Finally, the last common feature of the three 20th-century reforms is that all the reforms were carried out quickly because of the crisis and all of the reforms were disliked by the majority of society later on.

\section{Actors of education reforms}

Here we come to the last question, namely, who likes education reforms?

First of all, they are liked by reformers themselves. All the while, reformers deserve respect for their courage. They care, they want to improve education and therefore make society better. Even if they are not sure, they at least anticipate scepticism that awaits them and gets down to work notwithstanding. They strongly believe that this time they will succeed and that makes them strong. Reformers seek to institutionalize the ideals and dreams of society. They believe that they will succeed in making education modern, correct and innovative. They gather supporters, they have to be able to speak to different audiences, thus, they need to be strong, charismatic and persuasive. Reforms show who has the mandate to reform education - who is competent of society, who is an expert, who dares to talk about change in education. Reformers often have financial resources in their hands too. The reformer's position undoubtedly is that of a leader, a position of power and therefore attractive (Labaree, 2012, 153, 160, Apple, 2015, 13, Terhart, 2013, 487).

However, an education reform of any scale sooner or later has to be translated into educational practice, and teachers who "feel forced to take part in reform and development process" (Terhart, 2013, 487) are made responsible for this translation.

The research on the emotions of Latvian, Lithuanian, Estonian and Russian teachers when they remember the education reforms of the 1990s demonstrated that only some teachers think of that time with 
positive emotions, the majority characterises it as full of worries, fears, dissatisfaction, lack of understanding, stress, confusion and indifference. The emergence of new technologies and the comparison of educational outcomes formed a school elite, instilling the feeling of anxiety and injustice in teachers (Safronov.., 2018). When the study was presented at a conference, one of the questions from the audience, largely made up of educational historians, was whether it was possible to cite an example from history where the majority of teachers were satisfied with an education reform. No one knew of such a case. In a sense, this is about the collective memory in the teaching profession, which stores a feeling of uncertainty and insecurity in times of reforms.

Labaree adds that teachers see reforms as an interruption of practice, an intervention in the delicate ecology of the learning process (Labaree, 2012, 159). Ewald Terhart mentions that proposing reforms to teachers can cause resentment - is their professional competence questioned and rated as bad? (Terhart, 2013, 488). David Tyack and Larry Cuban justify the scepticism of teachers, who are usually labelled as major opponents of reforms (Terhart, 2013, 489), saying that "sometimes teachers have been wise to resist reforms that violated their professional judgement" (Tyack, Cuban, 2003, 5). Resistance to reforms cannot be simply measured as "backwardness", for sometimes it is the voice of common sense. Teachers, who similarly to the major part of society are constantly dissatisfied with the situation in education, often want reforms, but not these reforms (Terhart, 2013, 488).

Definitely, the teacher audience is not homogeneous, unlike the relatively monolithic and relatively predictable group of reformers. Terhart subdivides teachers according to their attitudes towards reforms into the following groups: the rejectors, the disinterested, the 'wait and see' fraction, the hanger-on, the pragmatics, the cautious believers, and the ever enthusiastic - "whatever the reform's intention is" (Terhart, 2013, 491).

\section{Conclusions and discussion}

The current school system, as evidenced by "crisis rhetoric", does not satisfy society. Therefore, action is needed. But there is a paradox - the public does not like school, but in fact do not want to change it. What if the "new" turns out to be worse than the "old"? Errors during reforms are inevitable, as mistakes are part of the "new" (Burbules, 2016). And who will take responsibility for the chaos and mistakes pupils experience during their only time at school, for no one returns to school for the second time? And who is competent and capable of assessing long-term gains and losses of reforms if the introduction of innovations is believed to take at least 50 years? (Tyack, Cuban, 2003, 4). "Data-driven reflection" (Terhart, 
2013, 491) in educational space is increasingly criticised (see Waldow and Steiner-Khamsi, 2019, Lindblad, S., Pettersson, D., Popkewitz, 2018, Tröhler, 2014). As a historian of education, I am very keen of Tyack and Cuban's idea that the effectiveness of education reforms can in fact be evaluated only by a professional look at education history (Tyack, Cuban, 2003, 6-7). It is particularly important to emphasize this view at a time of "academic cleansing" (Rikowski, 2017, 4), of history being eradicated from the curriculum of teacher education, and when reformers "consider amnesia as a virtue" (Tyack, Cuban, 2003, 6).

Analysing history of crises, Bernard Hametsberger plays with the idea of what non-crisis education might look like. He argues that non-crisis is order, discipline, stability, regularity, continuity and peace (Hametsberger, 2018, 104). Thus, the ideal crisis-reform scenario could be as follows: defining and legitimizing the crisis - "correct" reforms by "right" actors peace and order in education, which is a utopia per se. Judging by history, however, the real crisis-reform scenario is as follows: a catastrophe in education - rapid reforms - critique of reforms - a gradual (from secret to increasingly visible) return to past practices.

The failure and repetition of reforms are determined by interests of various "players". Reformers, consumers of education (pupils and their parents), employers and teachers, all have their own personal agendas to realise in field of education. To reconcile their interests is a good but rather utopian project.

However, reforms also have their "silver lining": any reform activates school practice, broadens teacher collaboration, and forces the public to debate education. The wave of reforms brings education and teachers to the top. All that remains is to agree with Burbules that "education, because it is an intrinsically challenging and imperfect practice, is always looking for ways to improve, and this has led to a constant cycle of reform, optimism, disappointment, and then new reform" (Burbules, 2016, 9).

\section{References}

Abbs, P. (2003). Against the Flow: Education, the Arts and Postmodern Culture. New York: Routledge Falmer.

Apple, M. W. (2015). Reflections on the Educational Crisis and the Tasks of the Critical Scholar/Activist. Nordic Journal of Pedagogy and Critique, 1, 1-17.

Arsenjev, A. M., Dodonov, V. I., Kolmakova, M. N., Pancin, F.G., Pavkin Z. I. (1988). Ocerki istorii skoli i pedagogiceskoj mislji narodov SSSR. 1941-1961 [Essays on history of school and pedagogical thought of USSR nations. 1941-1961]. Moskva: Pedagogika.

Burbules, N. C. (2016). Technology, Education, and the Fetishization of the 'New.' In: Smeyers, P., Depaepe, M. (Eds.) Educational Research: Discourses of Change and Changes of Discourse (pp. 9-16). Springer International Publishing. 
Chankseliani, M., Silova, I. (Eds.) (2018). Comparing Post-Socialist Transformations: Purposes, Policies, and Practices in Education. Oxford Studies in Comparative Education.

Coumel, L. (2009). The Scientist, the Pedagogue and the Party Official. Interest Groups, Public Opinion and Decision-Making in 1958 Educational Reform. In: Ilic, M., Smith, J. (Eds.) Krushchev in the Kremlin: State and Society (pp. 66-85). London: Routledge.

Dauge, A. (1922). Darba skolas jaunākais virziens [The latest direction of the Arbeitschule]. Students, 15.11.

Gintere, L. (2000). Krīze izglìtībā apdraud visas valsts nākotni [The crisis in education threatens the whole country's future]. Latvijas Vēstnesis, 24.05.

Hemetsberger, B. (2018). Burbunkologie oder: Zur Bearbeitung von Bildungskrisen. Pädagogische Korrespondenz, 57, 101-112.

Hopmann, S. T. (2008). No Child, No School, No State Left Behind: Schooling in the Age of Accountability. Journal of Curriculum Studies, 40 (4), 417-456.

Hutt, E. L. (2016). The "Crisis" Problem: On the Pervasiveness of Crisis Rhetoric in American Education Research. In: Smeyers, P., Depaepe, M. (Eds.) Educational Research: Discourses of Change and Changes of Discourse (pp. 153-172). Cham: Springer.

Johansons, A. (1975). Latvijas kultūras vēsture 1710-1800 [History of Latvia's Culture 1710-1800]. Sweden: Daugava.

Ķestere, I. (2010). Tradīcijas un modernisms Latvijas skolās neatkarīgas valsts veidošanās periodos: kas ir mainījies kopš 1920.gada? [Traditions and modernity in the schools of Latvia during formation of independent state: what has changed since 1920?] In: Krūze, A., Kestere, I. (Eds.) Pedagoğijas vēsture. 15 jautājumi. Zinātnisku rakstu krājums [History of education: 15 questions. Collection of articles] (pp. 36-50). Rīga: RaKa.

Ķestere, I. Lāce, T. (2004). Padomju skola: ieskats tās raksturojumā un vērtējumos [Soviet school: Insights into its characteristics and evaluation]. Latvijas Universitātes raksti. Pedagogija un skolotāju izglitỉba [Acta Universitatis Latviensis. Pedagogy and teacher education], 670, 34-43.

Labaree, D. F. (2012). School Syndrome: Understanding the USA's Magical Belief That Schooling Can Somehow Improve Society, Promote Access, and Preserve Advantage. Journal of Curriculum Studies, 44 (2), 143-163.

Lindblad, S., Pettersson, D., Popkewitz, T.S. (Eds.) (2018). Education by the Numbers and the Making of Society. The Expertise of International Assessments. New York: Routledge.

Marsone, S., Kestere I. (2010). Reformpedagoǵijas attīstība Latvijā Eiropas reformpedagogu kustības kontekstā [Development of Reformpädagogik in Latvia in the European context]. In: Krūze, A., Ķestere, I. (Eds.) Pedagoǵijas vēsture. 15 jautājumi. Zinātnisku rakstu kräjums [History of education: 15 questions. Collection of articles] (pp. 118-139). Rīga: RaKa.

Rikowski, G. (2017). Critique of the Classical Theory of Education Crisis. Paper for International Seminar for Public Pedagogies 'Crises and Education'. University of East London. Downloaded from https://www.academia.edu/35164258/ Critique_of_the_Classical_Theory_of_Education_Crisis

Rose, R. (2009). Understanding Post-Communist Transformation. A Bottom Up Approach. London and New York: Routledge.

Safronov, P., Erss, M., Loogma, K., Pranckuniene, E. (2018). Tears Apart: Teachers Emotions and Educational Reforms in Estonia, Lithuania and Russia in 1980s and 1990s. Downloaded from https://eera-ecer.de/ecer-programmes/conference/23/contribution/43888/

Scheibe, W. (1999). Die reformpädagogische Bewegung. Weinheim und Basel: Beltz Verlag. 
Seleckis, V. (1995). Vai tikai izglītības krīze? [Is it only the education crisis?] Neatkarìgā Cīna, 11.05.

Soste, M. (1920). Skolnieku pašvaldība skolās [Students' self-government in schools]. Latvijas Skola, 6/7.

Tenorth, H. E. (1999). Nachwort. Reformpädagogik und Ihre Historiographie und Analyse. In: Scheibe, W. Die reformpädagogische Bewegung (pp.438-449). Weinheim und Basel: Beltz Verlag.

Terhart, E. (2013). Teacher Resistance against School Reform: Reflecting an Inconvenient Truth. School Leadership \& Management, 33 (5), 486-500.

Tyack, D., Cuban, L. (2003). Tinkering Toward Utopia. A Century of Public School Reform. Harvard University Press.

Tröhler, D. (2014). Change Management in the Governance of Schooling: The Rise of Experts, Planners and Statistics in the Early OECD. Teachers College Record, 116 (9), 13-26.

Vēbers, E. (2007). Krīzes centrā - skola [School in the centre of the crisis]. Latvija Amerikā, 22.09.

Vītīna, A. (1958). Skolu saistīt ar dzīvi [Link school to life]. Zemgales Komunists, 29.11.

Waldow, F., Steiner-Khamsi G. (Eds.) (2019). Understanding PISA's Attractiveness: Critical Analyses in Comparative Policy Studies. Bloomsbury Academic.

Zigmunde, A. (2010). Hugo Gaudig. Pädagogische Konzeption und sein Besuch im Baltikum in Herbst 1922. Riga: Verlag der Technischen Universität Riga. 